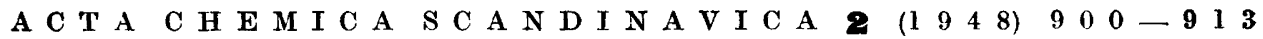

\title{
Chemical Studies on the Jelly Coat of the Sea-Urchin Egg
}

\author{
ERIKVASSEUR
}

Wenner-Grens Institute for Experimental Biology, University of Stockholm, Stockholm, Sweden

$I^{n}$

n normal sea-water the jelly coat of the sea-urchin egg slowly increases in volume and goes into solution. This process was demonstrated by Herbst ${ }^{1}$ to be greatly accelerated when the $\mathrm{pH}$ of the sea-water is lowered sufficiently. Lillie ${ }^{2}$ made the interesting observation that sea-urchin sperm are activated and agglutinated by homologous egg-water, $i$. e., sea-water which has been in contact with eggs of the same species. While he was of the opinion that the agglutinating agent, fertilisin, was continuously secreted by the egg, subsequent investigations did not support this view. Instead, fertilisin has been proved to arise from the jelly coat of the egg. The reader is referred to the excellent review by Tyler ${ }^{3}$. This evidence and the importance which has been attributed to fertilisin in the process of fertilisation ${ }^{2-4}$ has aroused great interest in the chemical composition of the jelly coat substance ${ }^{5-7}$ and of fertilisin ${ }^{8}$.

In order to obtain more precise analytical data on the nature of the carbohydrate and protein components, as well as elementary analyses, of the jelly coat substance from different sea-urchin species, the following study was undertaken.

\section{EXPERIMENTAL}

Material and preparation

For the present investigation, the jelly coat of the following sea-urchin species was used: from the Swedish west coast, Kristineberg Zoological Station, Strongylocentrotus droebachiensis (O. F. Müller), Echinus esculentus (Linné), Psammechinus miliaris (Gmelin), Echinocardium cordatum (Pennant), and Brissopsis lyrifera (Forbes); from Station Biologique, Roscoff, Paracentrotus lividus (Lamarck), and from Naples, frozen-dried eggwater of Arbacia lixula (Linné)*.

* Generously supplied by Fil. mag. Tore Hultin. 


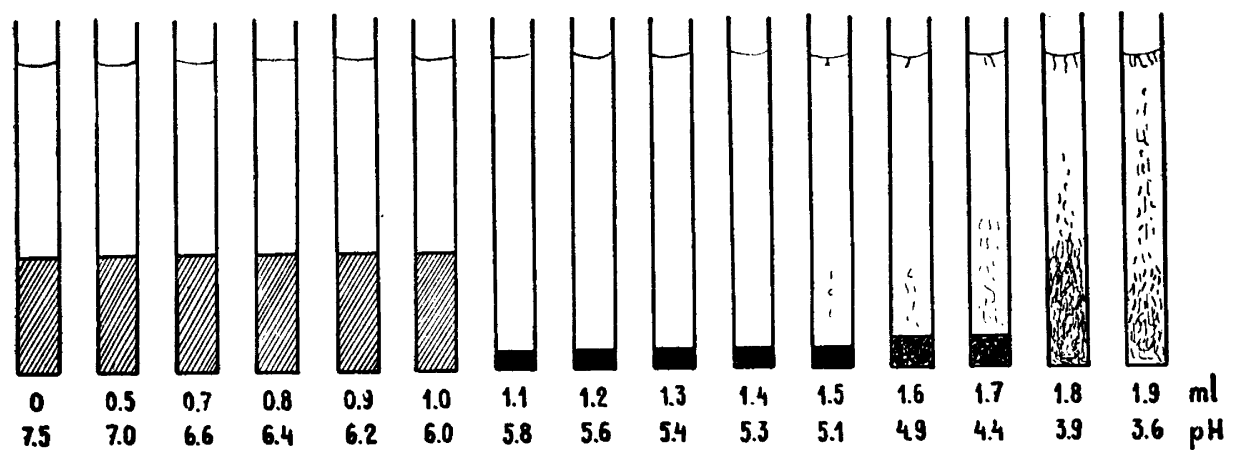

Figure 1. A diagram of the test for removal of the jelly coat of Echinus esculentus eggs at different $p H$. Each tube contains $2 \mathrm{ml}$ egg suspension and different amounts of $0.01 \mathrm{~N}$ $\mathrm{HCl}$ (upper row); total volyme $6 \mathrm{ml}$. For further explanation see text.

The sea-urchin eggs were washed several times by sedimentation in sea-water and their jelly coat was removed by treatment with acid sea-water; the appropriate pH for this was investigated for each sea-urchin species. Into small flat-bottomed test tubes $(10 \times 90 \mathrm{~mm}), 0-2.0 \mathrm{ml}$ of $0.01 \mathrm{~N} \mathrm{HCl}$ in sea-water was pipetted. The volume was adjusted to $4 \mathrm{ml}$ with sea-water and the solution was mixed, whereafter $2 \mathrm{ml}$ of $\mathrm{ggg}$ suspension was added to each tube in rapid succession. In order to obtain homogenous suspensions, the tubes were inverted several times and then allowed to stand undisturbed. An inspection of the tubes clearly showed in which tubes the eggs were deprived of their jelly coats, since these eggs sedimented more rapidly and, when packed on the bottom, occupied less space than those with jelly coats, as illustrated in Fig. 1. The pH was determined in the clear supernatant, after centrifuging when necessary, with a Beckman pH-meter. For Echinus esculentus, the jelly coat was completely dissolved without injury to the eggs between $\mathrm{pH}$ 5.0-5.8. In the $\mathrm{pH}$ interval 4.0-5.0, the jelly dissolved, but simultaneously some of the eggs were destroyed. Below pH 4.0 even more eggs cytolysed. Above pH. 6.0, there was no difference from the eggs in normal sea-water. A pH near the upper limit was used for the preparative work in order to avoid degradation of the jelly coat substance (cf. below). This limit is for Strongylocentrotus droebachiensis at pH 5.6, Echinus esculentus 5.8, Echinocardium cordatum 5.1, and Psammechinus miliaris 5.3.

The egg suspension was centrifuged after some minutes acid treatment and the supernatant jelly coat solution decanted off and cleared by repeated strong centrifugings. When necessary, the solution was also filtered. In some experiments, this clear colourless jelly solution was directly dialysed without prior precipitation. Concentration by freezing and thawing was also employed. Usually the gelatinous substance was best precipitated with either ammonium sulphate or alcohol and ether. For the complete precipitation of Echinus esculentus jelly substance with ammonium sulphate, an almost saturated solution was required and resulted in a very viscid precipitate, whereas only about 70 per cent saturation was necessary for Strongylocentrotus droebachiensis giving, in this case, a firm fibrous precipitate which could easily be collected with a spoon. On the 
other hand, precipitation with 1 volume of alcohol and 0.2 volumes of ether was most convenient for Echinus esculentus, since a coherent fibrous mat formed on the surface. The Strongylocentrotus droebachiensis jelly substance, precipitated under these conditions, did not accumulate at the surface but was distributed through the whole solution and settled only slowly. To precipitate the Paracentrotus lividus jelly substence, two volumes of 96 per cent alcohol were necessary to obtain a clear solution; with one volume, the supernatant remained opalescent due to incomplete precipitation of calcium sulphate from the sea-water. One volume of alcohol added to Psammechinus miliaris jelly solution however gave a clear supernatant. Obviously, these differences in precipitation indicate differences in the composition of the various jelly substances.

The precipitates were collected with a spoon or glass rod and most of the solution was pressed out of the fibrous mass. In this state, the gelatinous substance may be preserved in the cold for long periods.

For further purification, the fibrous precipitate was dialysed in a cellophane tube against running tap-water and finally against distilled water until completely free of chloride and sulphate ions. During this process, the substance dissolved and a very viscous solution was obtained. The ammonium sulphate precipitated substance dissolved more readily than the alcohol and ether precipitates and gave a more viscous solution. The jelly coat substance was obtained in a very suitable dry form by freeze-drying this concentrated solution. All samples of jelly substance used in this investigation were frozendried unless otherwise stated. They contained 4-15 per cent moisture.

In the tables the following abbrevations are used for the different methods of preparation: $\mathrm{Am}_{2} \mathrm{SO}_{4}=$ precipitation with ammonium sulphate; Alc. = precipitation with 96 per cent alcohol; Alc. $+\mathrm{Et}_{2} \mathrm{O}=$ precipitation with alcohol and ether; Thawing $=$ the jelly solution is frozen in cubes, the cubes crushed in a mortar and poured in a funnel; only the more viscous portions were kept for further treatment. All these preparations were completed by dialysis and freeze-drying. Not pptd. = direct dialysis, followed by freeze-drying. Alc. $+\mathrm{Et}_{2} \mathrm{O}$, eldial. $+=$ precipitation with alcohol and ether, dialysis, electro-dialysis, plus-fraction, freeze-drying.

\section{Chemical analyses}

\section{Carbohydrate}

A. Orcinol and sulphuric acid reaction

The chemical nature of the carbohydrate in the jelly coat ${ }^{6}$ was investigated with the orcinol and sulphuric acid method of Vasseur ${ }^{9}$. The colour curves obtained with the jelly coat solutions of Strongylocentrotus droebachiensis, Echinocardium cordatum, and Paracentrotus lividus did not correspond to the colour curves for hexoses or pentoses, but very good agreement was found with the colour curves for the methylpentose, rhamnose. On the other hand, the jelly coat solution of Echinus esculentus gave colour curves corresponding well with those of the aldohexoses. It was difficult to decide, however, with this method which particular aldohexose it was. Immers, in collaboration 
with the author, recently has studied the carbohydrate component of Echinus esculentus jelly with the aid of paper chromatography and has shown that it is most probably identical with galactose and not with mannose or glucose.

With Strongylocentrotus droebachiensis jelly solution, more detailed studies were carried out with the orcinol colour reaction. An extra heating time of 5 minutes was found necessary to give colour curves comparable with those of rhamnose. Thus, 10 and 25 minutes heating gave colour curves of the same form as the 5 and 20 minute curves of rhamnose, respectively. This retardation of colour development depends upon the extra time required to release from the polysaccharide molecule, the furfural derivatives which react with the orcinol. Quantitative estimations by this colorimetric method showed a carbohydrate content of approximately 39 per cent, calculated as polyrhamnose.

On different preparations of Echinus esculentus jelly solutions, colour curves for 20 minutes heating were made. These were identical regardless of whether the jelly solution was only dialysed, was precipitated by ammonium sulphate or alcohol and ether and then dialysed, or was electrodialysed after precipitation, and the plus- or minus-fractions tested.

\section{B. Chromic acid oxidation}

In order to obtain more reliable values of carbohydrate content, two determinations * with the quantitative chromic acid oxidation of Lemieux and Purves ${ }^{10}$ were made on the Strongylocentrotus droebachiensis jelly substance.

Analysis: Two lots of $L(+)$ rhamnose (Hoffmann-LaRoche, $20 \mathrm{mg}$ each) gave 34.60 and 34.85 per cent acetic acid; calculated 36.59 per cent. This corresponds to 95 per cent yield.

Two lots of Strongylocentrotus droebachiensis jelly substance (50 mg each) gave 16.63 and 18.76 per cent acetic acid; assuming 95 per cent yield, 17.90 and 19.75 per cent, respectively. This corresponds to $\mathbf{4 2 . 6}$ and $\mathbf{4 8 . 1}$ (mean 45.3 ) per cent poly-methylpentose in the jelly coat substance.

A further identification of the carbohydrate component is under investigation.

$$
\text { C. Hexosamine and hexuronic acid }
$$

Hexosamine was estimated in Echinocardium cordatum jelly substance ** using the modification of Nilsson ${ }^{11}$ of the method of Elson and Morgan.

* These analyses were generously performed by Mrs. Eva Borenstein at Professor Erik Jorpes' laboratory.

** This analysis was generously performed by Mr. Evert Lindberg at Professor Gunnar Blix' Laboratory. 
Hexuronic acid was determined in Echinocardium cordatum * and in Strongylocentrotus droebachiensis** jelly substances according to Burkhart, Baur, and Link ${ }^{12}$. No hexuronic acid was detectable, and the hexosamine content was very small, perhaps insignificant.

D. "Gl y c o g e n"

One analysis of "glycogen» according to Meyerhof and Lohmann ${ }^{13}$ was carried out on Echinocardium cordatum jelly coat solution and 4 analyses according to Lindberg ${ }^{14}$ on Echinus esculentus jelly solution.

Analysis: $1.5 \mathrm{~g} \mathrm{KOH}$ was dissolved in $5 \mathrm{ml}$ of 0.045 per cent Echinocardium cordatum jelly solution. The sample was hydrolysed 2 hours at $100^{\circ}$, chilled, precipitated with 2 volumes of absolute alcohol, and allowed to stand overnight. The precipitate was centrifuged, washed twice with absolute alcohol, once with ether, and dried in a desiccator over blue silica gel. The dry residue was suspended in $10 \mathrm{ml}$ of $2.5 \mathrm{~N} \mathrm{HCl}$, and hydrolysed 3 hours at $100^{\circ}$, chilled, and neutralised to phenolphthalein with $\mathrm{NaOH}$. The volume was adjusted to $20 \mathrm{ml}$ and the reducing value in two aliquots, 3.0 and $5.5 \mathrm{ml}$, was determined according to the method of Hagedorn and Jensen ${ }^{15}$. Found: $76 \gamma$, and $115 \gamma$, respectively, as glucose, corresponding to $\mathbf{2 2 . 5}$ and $\mathbf{1 8 . 6}$ (mean 20.0) per cent of the jelly substance.

Echinus esculentus jelly: two samples were hydrolysed in 30 per cent $\mathrm{KOH}$ and two samples in 40 per cent $\mathrm{KOH}$ and treated according to Lindberg ${ }^{14}$ for total glycogen content. Result: 14.6, 14.3, 13.0, and 14.0 per cent of the jelly substance as "glucose". Treatment of the alcohol precipitate with half-saturated sodium sulphate did not change these figures.

\section{Elementary analysis}

A. Carbon, hydrogen, and ash

The automatic semi-micro elementary analysis apparatus of Reihlen and Weinbrenner ${ }^{16}$ was used, and the results are summarised in Tables 1 and 2.

Table 1. Carbon, hydrogen, and ash content of Echinocardium cordatum jelly coat substance.

\begin{tabular}{|c|c|c|c|c|c|}
\hline \multirow{2}{*}{\multicolumn{2}{|c|}{$\frac{\text { Sample }}{\text { Preparation } \mathrm{mg}}$}} & \multirow{2}{*}{$\begin{array}{c}\mathrm{C} \\
\text { per cent }\end{array}$} & \multirow{2}{*}{$\begin{array}{c}\mathrm{H} \\
\text { per cent }\end{array}$} & \multicolumn{2}{|c|}{ Ash } \\
\hline & & & & $\mathrm{mg}$ & per cent \\
\hline \multirow{2}{*}{$\mathrm{Am}_{2} \mathrm{SO}_{4}$} & $\int 39.80$ & 23.95 & 5.70 & 8.60 & 21.60 \\
\hline & 22.60 & 25.1 & 5.4 & 4.7 & 20.8 \\
\hline \multirow{2}{*}{ Not pptd. } & 25.65 & 12.5 & 4.40 & 11.85 & 46.2 \\
\hline & 36.40 & 11.6 & 4.40 & 17.00 & 46.7 \\
\hline
\end{tabular}

* This analysis was generously performed by Mr. Evert Lindberg at Professor Gunnar Blix' laboratory.

** These analyses were generously performed by Mrs. Eva Borenstein at Professor Erik Jorpes' laboratory. 
Table 2. Elementary composition of Strongylocentrotus droebachiensis jelly coat substance:

$C, H$, ash, $S, C a$, and $N$.

\begin{tabular}{|c|c|c|c|c|c|c|c|c|c|}
\hline Analysis & $\begin{array}{l}\text { S a m p le } \\
\text { Preparation }\end{array}$ & $\mathrm{mg}$ & $\begin{array}{c}\mathrm{C} \\
\text { per cent }\end{array}$ & $\begin{array}{c}\mathbf{H} \\
\text { per cent }\end{array}$ & $\begin{array}{c}\text { Aṣh } \\
\text { per cent }\end{array}$ & $\begin{array}{c}\mathrm{S} \text { in ash } \\
\text { per cent of } \\
\text { whole sample }\end{array}$ & $\begin{array}{l}\text { Total } \\
\mathbf{S} \\
\text { per cent }\end{array}$ & $\begin{array}{c}\text { Ca } \\
\text { per cent }\end{array}$ & $\begin{array}{c}\mathrm{N} \\
\text { per cent }\end{array}$ \\
\hline Ea $46: 1$ & & 31.46 & 22.7 & 4.32 & 39.8 & 8.5 & & & \\
\hline Ea $46: 7$ & & 26.98 & 20.6 & 4.27 & 44.0 & & & & \\
\hline GK $47: 3$ & Alc. $+\mathrm{Et}_{2} \mathrm{O}$ & 25.04 & & & 41.5 & 9.2 & 11.2 & & \\
\hline $\mathrm{Kj} \quad 48: 14$ & & | 26.6 & & & & & & & 4.02 \\
\hline Ea $\quad 46: 2 a$ & & / 32.38 & 26.48 & 5.07 & 34.4 & & & 9.1 & \\
\hline $\mathrm{Ea} \quad 46: 2 \mathrm{~b}$ & Alc. $+\mathrm{Et}_{2} \mathrm{O}$ & 36.46 & 25.62 & 5.23 & 35.8 & & & 7.5 & \\
\hline
\end{tabular}

$\mathrm{Ea}=$ elementary analysis ${ }^{18}, \mathrm{GK}=$ total sulphur determination ${ }^{19}, \mathrm{Kj}=$ total nitrogen determination ${ }^{21}$.

Sulphate was determined on the ash of elementary analysis Ea $46: 1$ according to the benzidine sulphate method of MoKittrick and Schmidt ${ }^{17}$. The figure obtained is certainly too low to represent the total sulphur content of the sample. Determinations with the Grote and Krekeler apparatus (cf. below) show that some of the sulphur is always carried away from the ship by the air-stream.

On the ash of analyses Ea $46: 2 a$ and $b$ (cf. Table 2) calcium determinations were made according to the method of de Loureiro and Janz ${ }^{18}$. The data show that in this preparation which was precipitated with alcohol, the major share (70-90 per cent) of the cations is calcium. It is however probable that alcohol precipitation promotes an enrichment of the calcium in the preparation since calcium sulphate is the first salt to be precipitated from sea-water upon addition of alcohol. Upon dialysis of the jelly substance together with the calcium sulphate, the calcium ions may replace other cations in the substance to some extent.

B. Sulphur. a. Total sulphur

For total sulphur determinations, the jelly coat substance was combusted in the Grote and Krekeler apparatus ${ }^{19}$, and the sulphate determined as benzidine sulphate by titration with $0.01 \mathrm{~N} \mathrm{NaOH}{ }^{17}$, both in the ash and in the absorption liquid. The results are given in Table 3. 
Table 3. Sulphur analyses on the jelly coat substance of different sea-urchin species; cf. also Tables 2 and $\%$.

\begin{tabular}{|c|c|c|c|c|c|c|}
\hline \multicolumn{3}{|l|}{ Sample } & $\begin{array}{l}\mathrm{S} \text { in } \\
\text { ash }\end{array}$ & $\begin{array}{l}\mathrm{S} \text { in abs. } \\
\text { liquid }\end{array}$ & \multirow{2}{*}{$\begin{array}{l}\text { Total S } \\
\text { per cent }\end{array}$} & \multirow{2}{*}{$\begin{array}{c}\text { Ash } \\
\text { per cent }\end{array}$} \\
\hline Species & Preparation & $\mathrm{mg}$ & \multicolumn{2}{|c|}{ per cent of whole sample } & & \\
\hline Echinus esculentus & Alc. $+\mathrm{Et}_{2} \mathrm{O}$ & 32.68 & 3.42 & 5.36 & 8.77 & 15.9 \\
\hline Wchinocardium cordatum & Not pptd. & 28.03 & 3.03 & 4.73 & 7.76 & 24.0 \\
\hline Paracentrotus lividus & Alc. & 34.03 & 4.70 & 3.54 & 8.24 & 22.0 \\
\hline Arbacia lixula & Not pptd. & 24.33 & 4.1 & 2.4 & 6.5 & 29.2 \\
\hline Brissopsis lyrifera & $\mathrm{Am}_{2} \mathrm{SO}_{4}$ & 34.25 & 1.14 & 1.54 & 2.68 & 8.47 \\
\hline
\end{tabular}

b. Acid-hydrolysable sulphate

Acid-hydrolysable sulphate was determined by hydrolysis with $0.05 \mathrm{~N}$ $\mathrm{HCl}$ in an autoclave at 2.5 atmospheres, followed by precipitation and titration as benzidine sulphate (cf. Vasseur ${ }^{7}$ ). Autoclaving for 30 minutes at 2.5 atm. was sufficient for an almost complete hydrolysis of the sulphate in Echinus esculentus jelly substance, as shown in Table 4.

For this investigation, an alcohol and ether precipitated sample was dialysed untiI free of chloride and sulphate ions. An accurately weighed sample of about $5 \mathrm{~g}$ of the resultant viscous solution was measured into a $100 \mathrm{ml}$ volumetric flask, mixed with an equal volume of $0.1 \mathrm{~N} \mathrm{HCl}$, and then placed in an autoclave. Fifteen to twenty minutes was allowed for the steam to displace the air, the vent was then closed, and a pressure of 2.5 atmospheres was reached within 5-10 minutes. For 0 hours autoclaving, the gas was switched off at this moment, and within 10 minutes the autoclave cooled to a pressure of 1 atmosphere after which the sample was removed. The dry weight of this jelly

Table 4. Hydrolysis of bound sulphate with $0.05 \mathrm{~N} \mathrm{HCl}$ in an autoclave at $2.5 \mathrm{~atm}$. pressure; Echinus esculentus jelly coat solution, precipitated with alcohol and ether, and dialysed.

\begin{tabular}{|c|c|c|c|c|c|}
\hline \multirow{2}{*}{$\begin{array}{c}\text { Time of heating } \\
\text { at 2.5 atm. } \\
\text { hours }\end{array}$} & \multicolumn{5}{|c|}{ Per cent free sulphate } \\
\cline { 2 - 6 } & \multicolumn{4}{|c|}{ Analysis no. } & Mean \\
\cline { 2 - 6 } & 1 & 2 & 3 & 4 & \\
\hline & & & & & \\
0.5 & 24.4 & 22.2 & 25.7 & 25.9 & 24.5 \\
3 & 30.4 & 32.5 & 30.9 & 31.4 & 31.3 \\
4 & 29.3 & 33.0 & 33.6 & 33.1 & 32.2 \\
\hline
\end{tabular}


solution was determined by heating in an oven to $105^{\circ}$ until constant weight was attained. The obtained sulphate values are therefore higher than those for the frozen-dried samples which contained 4-15 per cent moisture. Two determinations of total sulphur gave 11.1 ond 11.0 per cent (33.2 and 33.1 per cent $\mathrm{SO}_{4}$ ). Total nitrogen was 2.17 per cent.

$$
\text { C. Total phosphorus }
$$

About 0.5 per cent total phosphorus in Echinocardium cordatum jelly and about 0.4 per cent in Strongylocentrotus droebachiensis jelly were obtained by the method of Briggs ${ }^{20}$.

\section{Total nitrogen}

期

Total nitrogen was determined according to the procedure of Parnas 21 using the combustion fluid of Arnold and Wedemeyer (cf. Parnas). The ammonia was driven off by $10 \mathrm{ml}$ of 30 per cent $\mathrm{NaOH}$ containing $30 \mathrm{~g}$ of $\mathrm{Na}_{2} \mathrm{~S}_{2} \mathrm{O}_{3}$ per liter, absorbed in $4 \mathrm{ml}$ of 2 per cent $\mathrm{H}_{3} \mathrm{BO}_{3}$, and titrated with $0.01 N \mathrm{HCl}$ using the Tashiro indicator $(100 \mathrm{ml} 0.03$ per cent methyl red solution and $15 \mathrm{ml} 0.1$ per cent methylene blue solution) adjusted to the proper pH. The results are summarised in Table $5 *$.

\section{Amino acids}

Microbiological assay* was performed for threonine, valine, iso-leucine, histidine, arginine, and lysine, using Streptococcus faecalis growing on the basal

Table 5. Total nitrogen in different jelly coat preparations; cf. also Tables 2 and 8.

\begin{tabular}{|c|c|c|c|c|c|}
\hline \multicolumn{2}{|c|}{ Sample } & \multirow{2}{*}{$\begin{array}{l}\text { Total } N \\
\text { per cent }\end{array}$} & \multicolumn{2}{|c|}{ Sample } & \multirow{2}{*}{$\begin{array}{l}\text { Total } N \\
\text { per cent }\end{array}$} \\
\hline Preparation & $\mathrm{mg}$ & & Preparation & $\mathrm{mg}$ & \\
\hline \multicolumn{3}{|c|}{ Strongylocentrotus droebachiensis } & \multicolumn{3}{|c|}{ Paracentrotus lividus } \\
\hline Therwing & 27.4 & 5.30 & Alc. & 32.4 & 4.79 \\
\hline & & & \multicolumn{3}{|c|}{ Echinus esculentus } \\
\hline \multicolumn{3}{|c|}{ Echinocardium cordatum } & & 35.9 & 4.54 \\
\hline \multirow[t]{2}{*}{ Not pptd. } & 27.0 & 2.77 & $\mathrm{Am}_{2} \mathrm{SO}_{4} * *$ & 18.8 & 4.42 \\
\hline & 36.7 & 2.92 & & 20.8 & 4.42 \\
\hline & 48.5 & 3.47 & & 27.6 & 3.01 \\
\hline \multirow[t]{2}{*}{$\mathrm{Am}_{2} \mathrm{SO}_{4}$} & 28.2 & 3.52 & $\mathrm{Am}_{2} \mathrm{SO}_{4}$ & 25.9 & 3.02 \\
\hline & 28.8 & 3.82 & Alc. $+\mathrm{Et}_{2} \mathrm{O}$ & 31.4 & 2.77 \\
\hline & & & eldial. + & 21.5 & 2.03 \\
\hline
\end{tabular}

* I am indebted to Mag. Janis Immers for these analyses.

** Two ammonia-nitrogen determinations on this sample gave 1.61 and 1.50 per cent; this leaves 2.9 per cent as not-ammonia nitrogen. 
medium of Stokes and Gunness ${ }^{22}$, and for phenylalanine, tyrosine, proline, and lysine, using Leuconostoc mesenteroides growing on the basal medium of Henderson and Snell ${ }^{23}$. The results are summarised in Table 6, but may only be considered as approximate, owing to the small number of analyses. With paper chromatography aspartic acid and glutamic acid have been shown to be present. A rough estimation based on the colour intensities indicates an approximate amount of 1 or 2 per cent.

Table 6. Microbiological assay of some amino acids in the jelly coat substance of different sea-urchin species.

\begin{tabular}{|c|c|c|c|c|c|c|c|}
\hline \multirow{2}{*}{$\begin{array}{c}\text { Species: } \\
\text { Preparation: }\end{array}$} & \multirow{2}{*}{$\begin{array}{c}\begin{array}{c}\text { Paracen- } \\
\text { trotus } \\
\text { lividus }\end{array} \\
\text { Alc. }\end{array}$} & \multicolumn{2}{|c|}{ Echinus esculentus } & \multicolumn{2}{|c|}{$\begin{array}{l}\text { Strongylocentrotus } \\
\text { droebachiensis }\end{array}$} & \multirow{2}{*}{$\begin{array}{c}\begin{array}{c}\text { Echino- } \\
\text { cardium } \\
\text { cordatum }\end{array} \\
\mathrm{Am}_{2} \mathrm{SO}_{4}\end{array}$} & \multirow[b]{3}{*}{ Microorganism } \\
\hline & & $\mathrm{Am}_{2} \mathrm{SO}_{4}$ & $\begin{array}{l}\text { Alc. }+ \\
\text { Et }_{2} \mathrm{O}\end{array}$ & $\begin{array}{l}\text { Alc. }+ \\
\text { Et }_{2} \mathbf{O}\end{array}$ & $\begin{array}{l}\text { Alc. }+ \\
\mathrm{Et}_{2} \mathrm{O}\end{array}$ & & \\
\hline Amino acid & per cent & per cent & per cent & per cent & per cent & per cent & \\
\hline \multirow[t]{2}{*}{ Lysine } & 1.6 & 1.7 & 1.1 & $1 . \tilde{5}$ & 1.4 & 0.3 & $\begin{array}{l}\text { Streptococcus } \\
\text { faecalis }\end{array}$ \\
\hline & 1.4 & 1.4 & 0.5 & 0.9 & 1.2 & 0.3 & $\begin{array}{l}\text { Leuconostoc } \\
\text { mesenteroides }\end{array}$ \\
\hline Arginine & 2.0 & 1.8 & 1.9 & 1.9 & 1.9 & & $\begin{array}{l}\text { Streptococcus } \\
\text { faecalis }\end{array}$ \\
\hline Histidine & & 0.2 & & & & & $\begin{array}{l}\text { Streptococcus } \\
\text { faecalis }\end{array}$ \\
\hline Valine & 6.5 & 8.7 & 6.7 & 8.3 & 7.7 & 3.2 & $\begin{array}{l}\text { Streptococcus } \\
\text { faecalis }\end{array}$ \\
\hline Iso-leucine & & 1.8 & & 1.0 & & & $\begin{array}{l}\text { Streptococcus } \\
\text { faecalis }\end{array}$ \\
\hline Threonine & 2.0 & 1.6 & 1.2 & 2.1 & 1.8 & 2.0 & $\begin{array}{l}\text { Streptococcus } \\
\text { faecalis }\end{array}$ \\
\hline Phenyl-alanine & 1.0 & & 0.7 & 0.9 & 0.9 & 0.6 & $\begin{array}{l}\text { Leuconostoc } \\
\text { mesenteroides }\end{array}$ \\
\hline Tyrosine & 0.7 & & 0.5 & 0.7 & 0.7 & 0.3 & $\begin{array}{l}\text { Leuconostoc } \\
\text { mesenteroides }\end{array}$ \\
\hline Proline & 0.7 & & 0.6 & 0.9 & 0.7 & 0.3 & $\begin{array}{l}\text { Leuconostoc } \\
\text { mesenteroides }\end{array}$ \\
\hline Total N & 4.79 & 4.46 & 2.77 & 3.75 & 4.02 & 3.60 & \\
\hline
\end{tabular}


Table \%. Analyses after electrodialysis of $E$ chinus esculentus jelly coat solution (precipitated with alcohol and ether).

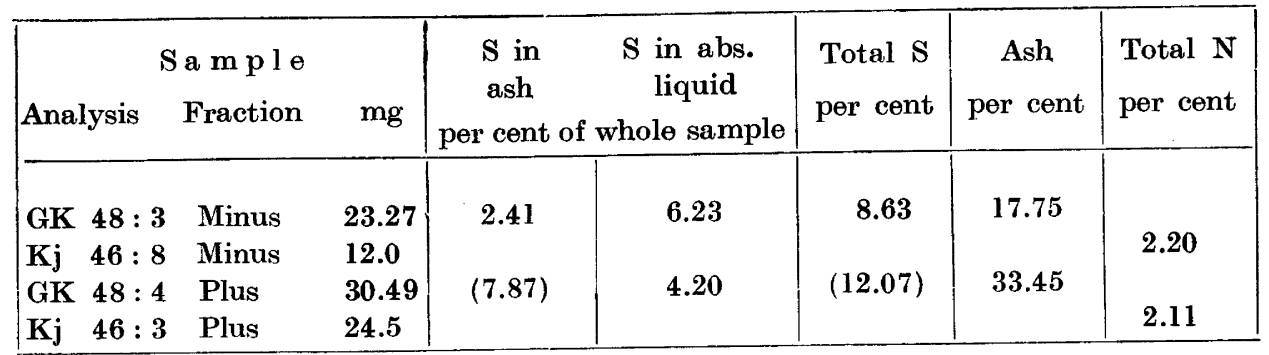

\section{Chemical analyses after electrodialysis}

Some of the preparations were further purified by electrodialysis. According to its acidic character ${ }^{6}$, the jelly coat substance migrated towards the anodic membrane. But whereas the Strongylocentrotus droebachiensis jelly formed a compact mass on the membrane, the Echinus esculentus jelly was concentrated only at the anodic compartment; plus- and minus-fractions of this latter jelly were therefore collected.

On the plus- and minus-fractions of one of these, namely an alcohol and ether precipitated Echinus esculentus preparation, determinations of total nitrogen $(\mathrm{Kj})$ and total sulphur $(\mathrm{GK})$ were performed, as seen in Table 7. The ash of the plus-fraction was unfortunately insoluble, probably because of high calcium sulphate content. Sulphur determination was therefore carried out only on the contents of the absorption vessel. However, if the assumption is made that the ash consists entirely of calcium sulphate, the values in the brackets are obtained. They are at least approximately valid since the calcium content is then 9.9 per cent, a fairly satisfactory agreement with the calcium content of Strongylocentrotus droebachiensis jelly substance precipitated with alcohol and ether.

\section{Chemical analyses after dialysis at $p H$ H-4}

A carefully dialysed sample of Strongylocentrotus droebachiensis jelly solution was redialysed against dilute hydrochloric acid of $\mathrm{pH} 3.9$ for one day, and then against dilute hydrochloric acid of $\mathrm{pH} 3.6$ for two more days. The dialysis was then continued against distilled water until free of chloride ions. After freeze-drying, the sample was analysed for total nitrogen $(\mathrm{K} \mathrm{j})$, total sulphur (GK), carbon, hydrogen, and ash (Ea). The values so obtained are compared with those for the original dialysed material (also frozen-dried), as shown in Table 8. The sulphur analysis $\mathrm{S} 46: 8$ is according to Vasseur ${ }^{7}$. 
Table 8. Analyses after dialysis against distilled water and against dilute hydrochloric acid at pH 3-4 of Strongylocentrotus droebachiensis jelly coat solution (precipitated with alcohol and ether).

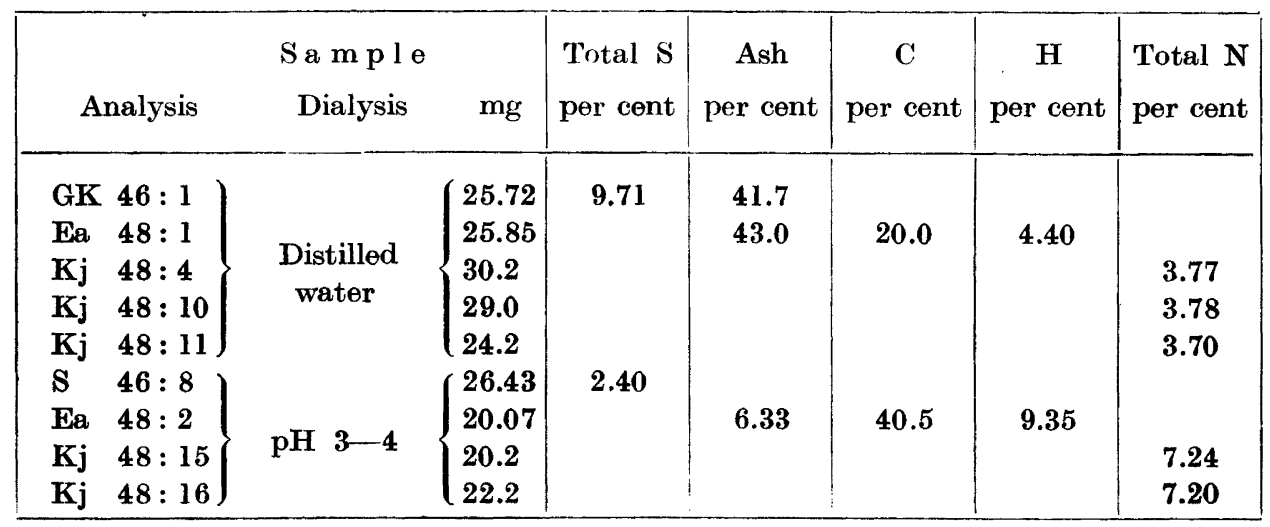

\section{DISCUSSION}

The values obtained for total sulphur and acid-hydrolysable sulphate (Tables 3 and 4) support the view that all or nearly all of the sulphur in the jelly coat substance exists in the form of ester-linked sulphate. The-analyses of total nitrogen (Table 5) and of the amino acids thus far conducted (Table 6) show that about 20-25 per cent of the jelly substance is composed of proteinor peptide-like material. All attempts to liberate this protein fraction or isolate the carbohydrate fraction have hitherto been fruitless. Electrodialysis removes some of the nitrogen, but the major part seems to be firmly bound (cf. Table 5). The strong linkage between the amino acids and the carbohydrate portion of the jelly substance, and the observation that the basic amino acids constitute only a small fraction of the total amino acids suggests that the amino acids are possibly bound in another fashion than by salt-linkage between basic groups of a protein and the acid polysaccharide. The analyses of the electrodialysed substance (Table 7) show that the cations are firmly bound and are preferentially carried to the anodic side.

The figures reported for carbohydrate, sulphate, total nitrogen, etc. are in accordance with the hypothesis of a protein-carbohydrate complex consisting of 20-25 per cent protein and 75-80 per cent polysaccharide esterified with one sulphate group per monosaccharide residue, the polysaccharide being a poly-methylpentose in the jelly coat substance of Strongylocentrotus droebachiensis, Paracentrotus lividus, and Echinocardium cordatum, and a polyhexose (probably a polygalactose) in the Echinus esculentus jelly. Since the 
methylpentose, fucose, is the most widely distributed in different marine algae, e.g., Fucus, Laminaria, the methylpentose in these jelly coats probably is also fucose.

The observation that the jelly coat in situ and in solution exhibits a strong metachromatic staining with toluidine blue, and the striking analogies between jelly coat substance and heparin ${ }^{24}$ constitute additional evidence for the view that the polysaccharide portion contains ester-linked sulphate.

The analyses given in Table 8 for jelly dialysed at $\mathrm{pH} \mathrm{3-4}$ show that the sulphate groups begin to hydrolyse even at this $\mathrm{pH}$. Tyler and Fox ${ }^{8}$ state that the agglutinin (the jelly coat solution) of Strongylocentrotus purpuratus is inactivated rapidly at $\mathrm{pH} \mathrm{2}$; this probably depends on the loss of sulphate groups. Since it has been shown ${ }^{25,26}$ that Brissopsis lyrifera egg-water and jelly solution do not exhibit any agglutination of sperms from the same species, it is interesting to note that the sulphur content of Brissopsis jelly is very low (Table 3). The presence of a sufficient number of sulphate groups may thus have a decisive rôle for the appearance of this reaction. The finding that sodium periodate destroys not only the blood coagulation inhibiting effect 24 but also the agglutinating activity of a jelly solution indicates further that the carbohydrate part is of utmost importance for the fertilisin mechanism ${ }^{23}$, whereas the protein fraction may be of significance for the species specificity of this reaction.

The positive reaction for glycogen given by Echinocardium cordatum and Echinus esculentus jelly certainly does not imply that the "glycogen" in the sea-urchin egg or in other organisms actually consists of this polysaccharide alone. A greater or lesser part of it instead may be of acidic character just as is the jelly coat substance. Monné ${ }^{27}$ recently demonstrated that the yolk fixed in Bouin's fluid may be stained only by certain acid dyes and by means of Best's carmine, Bauer's, and McManus and Hotchkiss' methods for detecting carbohydrates. From these facts, it is inferred that the yolk contains basic proteins and carbohydrates which cannot be glycogen because they are not attacked by saliva; possibly it is a mucous substance. The decrease of glycogen content after fertilisation found by Örström and Lindberg ${ }^{28}$ may represent a change in the content of a mucopolysaccharide which perhaps originated from the yolk. Lindberg ${ }^{14}$ showed furthermore that the major part of this "glycogen" is combined with protein, cf. also Hutchens, Keltch, Krahl, and Clowes ${ }^{29}$. Runnström ${ }^{30}$ demonstrated that there is a formation of aoid immediately after fertilisation and that this acid is not lactic acid. If the "glycogen" is truly a mucopolysaccharide, there exists the possibility that the acid formed upon fertilisation originates from this mucopolysaccharide. This aspect of the problem deserves further study. 


\section{SUMMARY}

Chemical analyses are presented on the jelly coat substance of the seaurchin egg, particularly from Strongylocentrotus droebachiensis, Echinus esculentus, and Echinocardium cordatum. Furthermore, some data are given on the jelly substance from Paracentrotus lividus, Brissopsis lyrifera, Arbacia lixula, and Psammechinus miliaris.

The gelatinous substance consists of about 20-25 per cent protein- or peptide-like material and $75-80$ per cent polysaccharide esterified with one sulphate group per monosaccharide residue, the polysaccharide being a polymethylpentose (probably polyfucose) for Strongylocentrotus droebachiensis, Echinocardium cordatum, and Paracentrotus lividus, and a polyhexose (probably polygalactose) for Echinus esculentus.

Different methods of preparation of the jelly coat substance are described.

The work has been supported by grants from the Rockefeller Foundation, the HiertaRetzius stipendiefond, Wilhelm Leches stipendiefond, E.W. Smitt's stipendiefond, H.S. och Emmy Josephsons stipendiefond, and the doktorandstipendium of the Swedish Government. I wish to express my warmest thanks to Professor John Runnström for the interest he has shown throughout this investigation and for the unfailing support he has always given me. I wish to especially thank Mr. Juhan Kuslap and Dr. med. Ivan Resch for valuable assistance during the study.

\section{REFERENCES}

1. Cf. Loeb, J. J. Exptl. Zool. 17 (1914) 132; Die chemische Entwicklungserregung des tierischen Eies (Künstliche Parthenogenese) Berlin (1909) 116.

2. Lillie, F. R. Science 36 (1912) 527; Problems of fertilization Chicago (1919).

3. Tyler, A. Physiol. Revs. 28 (1948) 180.

4. Runnström, J. Proc. VI. Intern. Congr. Exptl. Cytology. Stockholm (1947).

5. Kuhn, R., and Wallenfels, K. Ber. 73 (1940) 458; Wallenfels, K. Österr. Chem. Ztg. 43 (1940) 187.

6. Runnström, J., Tiselius, A., and Vasseur, E. Arkiv Kemi, Mineral. Geol. A 15 (1942) no. 16.

7. Vasseur, E. Arkiv Kemi, Mineral. Geol. B 25 (1947) no. 6.

8. Tyler, A., and Fox, S. Science 90 (1939) 516; Biol. Bull. 79 (1940) 153.

9. Vasseur, E. Acta Chem. Scand. 2 (1948) 693.

10. Lemieux, R. U., and Purves, C. B. Can. J. Research B 25 (1947) 485.

11. Nilsson, I. Biochem. Z. 285 (1936) 386.

12. Burkhart, B., Baur, L., and Link, K. P. J. Biol. Chem. 104 (1934) 171.

13. Meyerhof, O., and Lohmann, K. Biochem. Z. 171 (1926) 381.

14. Lindberg, O. Arkiv Kemi, Mineral. Geol. B 20 (1945) no. 1.

15. Cf. Rappaport, F. Mikrochemie des Blutes Wien and Leipzig (1935) 135; Barrenscheen, H. K., and Pany, J. Bestimmung von Kohlehydraten. In Bamann, E., and Myrbäck, K. Die Methoden der Fermentforschung, Leipzig. (1941) p. 1074. 
16. Reihlen and Weinbrenner D. R. P. 660105 8/10 (1933).

17. McKittrick, D. S., and Schmidt, C. L. A. Arch. Biochem. 6 (1945) 411.

18. de Loureiro, J. A., and Janz, G. J. Biochem. J. 38 (1944) 16.

19. Grote, W., and Krekeler, H. Angew. Chem. 46 (1933) 106; Schöberl, A. Angew. Chem. 50 (1937) 334.

20. Briggs, A. P. J. Biol. Chem. 53 (1922) 13.

21. Parnas, J. K. Z. anal. Chem. 114 (1938) 261.

22. Stokes, J. L., and Gunness, M. J. Biol. Chem. 157 (1945) 651.

23. Henderson, L. M., and Snell, E. E. J. Biol. Chem. 172 (1948) 15.

24. Immers, J., and Vasseur, E. Experientia (in press).

25. Vasseur, E., and Hagström, B. Arkiv Zool. A 37 (1946) no. 17.

26. Vasseur, E., and Carlsen, I. Arkiv Zool. A 41 (1948) no. 16.

27. Monné, L. Unpublished results.

28. Örström, Å., and Lindberg, O. Enzymologia 8 (1940) 367.

29. Hutchens, J. O., Keltch, A. K., Krahl, M. E., and Clowes, G. H. A. J. Gen. Physiol. 25 (1942) 717.

30. Runnström, J. Biochem. Z. 258 (1933) 257.

Received October 9, 1948. 